\title{
"A Study of Environmental Awareness among Post-Graduate Students of Distt Yamuna Nagar, Haryana"
}

\author{
*Ms Gunjan Bhatia, **Mrs. Mukta Bhatia, \\ Asstt Professor, Swami Vivekanand College Of Education, Jagadhri \\ Lecturer, Mukand Lal Public School, Yamuna Nagar
}

\begin{abstract}
Till a few hundred years ago man and nature has a satisfactory give and take arrangement and the system worked very well. There was no interference in the smooth working of the nature. The resources of the earth appeared to be vast and inexhaustible. No one could imagine that humans could bring any substantial change in the earth, but this proved to be a myth. Rapid increase in the human population has resulted in such large numbers of men and women that they virtually overcrowded the earth. With the increase in the needs of man there has been a manifold increase in the urbanization, industries, and agriculture and mining operations. We have therefore to make an appraisal of the present and predictable ecological, economic, social and political problems to stop the dangerous expansion with the advancement of technology and accumulated knowledge: we have to comprehend the danger in time to undertake the necessary steps to maintain a viable earth. The chief objective of the study is that individual, and social groups should acquire awareness and knowledge, develop attitudes, skills and abilities and participate in solving real life environmental problems. Environmental Education is a kind of education, which will seek to make people fully aware of the problems connected with their environment so that they may be able to tackle those problems with a sense of responsibility and with the technical skills which enable them to contribute to their solutions.
\end{abstract}

\section{Introduction}

Nature is fascinating. It embodies the spirit of its creator. The soft green leaf, moving gently in the breeze, the drops of dew quivering on the petal of a rose, the koel singing hidden in a mango grove, all are so enchanting, so enthralling. No less is the child with its hazel eyes, silken hair, rosy cheeks, toothless mouth and tender skin. Its father, man is perhaps the most unique creation of God. Man has made the world so beautiful. But for him nature would not been so enjoyable as it is he has converted wild forests into parks, garden, orchards and cities and deserves all praise for that, but in doing that in his attempt to make life more and more comfortable he has destroyed thoughtlessly, polluted air and water recklessly, despoiled nature ruthlessly. The inevitable consequence was an ominous deterioration of his environment. He did not stop even then. He, intact, jumped headlong towards environmental pollution and crisis. Environment is a very fascinating term. It is all inclusive, right from speck of dust to all blazing sun, all is environment. The term environment etymologically means surrounding. Environment is the sum total of all conditions and influences that effect the development and life of organisms. In the environment, pollutants are always present in physical, chemical and biological characteristics of our surroundings that have harmed the human life and other living species. The uncontrolled activities of human beings are damaging the healthy environment. There are many kinds of pollution, viz. air, water, noise etc. we are also surrounded with a curse of desertification, soil malady, floods and droughts, urban congestion, extinct and/or threat to many plants animals population growth has not been arrested. It's interesting to note that natural resources had been stored virtually untouched in the Earth for millions of years. But since the start of the industrial revolution vast amounts of these resources had been exploited within a period of just a couple of hundred of years at unimaginable rates, with all the waste from this exploitation going straight in to the environment (air, water, land) and seriously damaging its natural processes.

We have begun to discern the beginning of environment crisis as we are in the $21^{\text {st }}$ century. But in spite of all this all is not lost on the impending doom can be averted of reformed approach to resource consumption is adopted if awareness is created among students who are future citizens through Environmental Education. The most relevant to the subject is a Chinese perception about education, which says, " if you plan for one yearplant rice, if you plan for ten years-plant trees but if you plan for hundred years - educate people. " intact education is to be regarded as investment of the highest orders which in time to come become as assets. Most people recognize the urgent need for environment education. Environmental education is a learning process that increases people's knowledge and awareness about the environment and associated challenges, develops the necessary skills and expertise to address the challenges, and fosters attitudes, motivations, and commitments to make informed decisions and take responsible action (UNESCO, Tbilisi Declaration, 1978). The chief objective of Environmental Education is that individual and social groups should acquire awareness and knowledge, 
develop attitude and skills and abilities and participate in solving real life environmental problems. The perspective should be integrated, inter disciplinary and holistic in character.

The lay public in rural, tribal, slum, urban areas, women, students, teachers, planners, decision policy makers, program implementer etc. need to be educated about environment.

According to senate Report on Environmental Education Act, Washington D.C. 1970, "Environmental Education is an integrated process which deals with man's inter relationship with his natural an man made surroundings including the relation of the population growth, pollution resource allocation and depletion, conservation technology and urban and rural planning to the total human environment."

\section{OBJECTIVE OF THE STUDY}

The present study is undertaken keeping in view the following objectives:

- To study Environmental Awareness among Post-Graduate Students of District Yamuna Nagar.

- To study the differences in Environmental Awareness among Post-Graduate Male and Female students of District Yamuna Nagar.

- To study the differences in Environmental Awareness among Post-Graduate Students Science and Arts students of District Yamuna Nagar.

- To study the differences in Environmental Awareness among Post-Graduate Rural and Urban students of District Yamuna Nagar.

\section{HYPOTHESES}

- There exists no significant difference between Post-Graduate Male and Female Students regarding Environmental Awareness.

- There exists no significant difference between Post-Graduate Science and Arts Students regarding Environmental Awareness.

- There exists no significant difference between Post-Graduate Rural and Urban Students regarding Environmental Awareness.

\section{SAMPLE}

For the present study, the sample is selected from district Yamuna Nagar. The simple random sampling method was used in this study. 200 students were taken as the sample of the present study from various faculties which are given in the table.

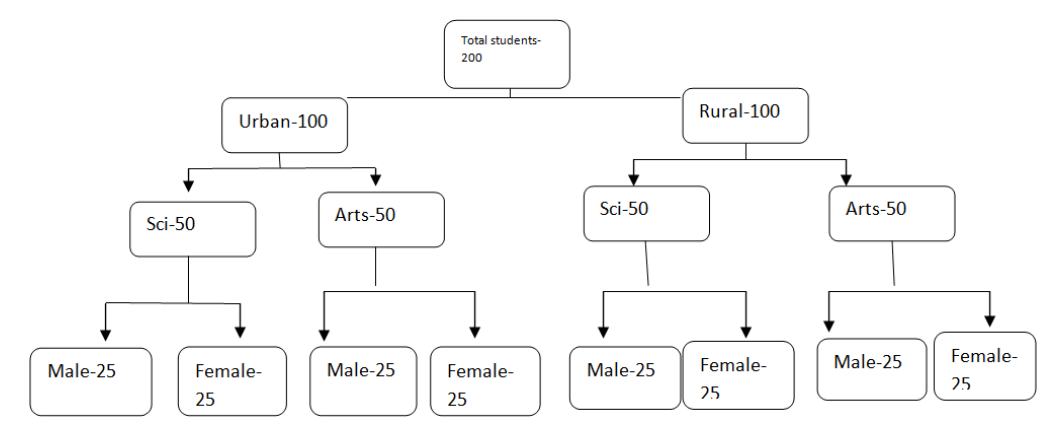

\section{Tools Used}

For the present study, the investigator used the Environmental Awareness Test (EAT) which was developed by A.Rajan Meetei (1996). The test consists of five components viz. general knowledge, air pollution, water pollution, land and soil pollution and noise pollution. The items are of multiple-choice type.

\section{Administration And Scoring}

For the collection of relevant data first permission was taken from the head of the institution and then started administering the test. For the administration of "Environmental Awareness Test(EAT) "questionnaires were given to the students. The test contains 51 questions. All the questions were in the form of objective type. Four alternatives were given against each question and the subject was to choose only one correct answer. One mark was awarded for wrong answer. In this way, the sum total of marks received by individual students on the Environmental Awareness Test was considered as his/her Environmental Awareness Test scores.

\section{Analysis}

The main purpose of the present study is to study the environment Awareness among the post graduate students. In the present study the measure of central tendency(arithmetic mean, median,mode), the measure of 
“A Study Of Environmental Awareness Among Post-Graduate Students Of Distt Yamuna Nagar,

dispersion(S.D.), and the measure of skewness and kurtosis were applied to study the normality of the data. " $\mathrm{t}$ " test was applied to study the significant difference between Male and Female, Arts and Science, Urban and Rural groups studying in postgraduate colleges of district Yamuna Nagar.

\section{FINDING}

From the analysis and interpretation of the data, the following findings were drawn:

- $\quad$ COMPARISON OF MEAN, S.D. AND C.R. BETWEEN MALE AND FEMALE POST-GRADUATE STUDENTS

\begin{tabular}{|l|l|l|l|l|l|l|l|}
\hline GROUP & $\mathrm{N}$ & $\sum \mathrm{X}$ & $\mathrm{M}$ & & $\mathrm{SEd}$ & t-ratio & $\begin{array}{l}\text { Level of } \\
\text { significance }\end{array}$ \\
\hline Male & 100 & 3440 & 34.40 & 6.266 & 0.916 & 1.45 & $\begin{array}{l}\text { Not } \\
\text { significant }\end{array}$ \\
\hline Female & 100 & 3307 & 33.07 & 6.766 & & & \\
\hline
\end{tabular}

It can be observed from the given table that the Environmental Awareness scores of Post-Graduate Male and Female students are found to have mean score of 34.40 and 33.07 and S.D. is 6.266 and 6.766 respectively. The' $t$ ' ratio between two groups has been found out to be 1.45 which is less than 1.96 , so it is not significant at 0.05 level. It means that there exists no significant difference between Post-Graduate Male and Female students regarding Environmental Awareness.

Thus the hypothesis that there exists no significant difference between Post-Graduate Male and Female students regarding Environmental Awareness is accepted. STUDENTS

COMPARISON OF MEAN, S.D. AND C.R. BETWEEN ARTS AND SCIENCE POST-GRADUATE

\begin{tabular}{|l|l|l|l|l|l|l|l|}
\hline GROUP & $\mathrm{N}$ & $\sum \mathrm{X}$ & $\mathrm{M}$ & & SEd & t-ratio & $\begin{array}{l}\text { Level } \\
\text { significance }\end{array}$ \\
\hline Arts & 100 & 3288 & 32.88 & 6.143 & 0.916 & 1.87 & $\begin{array}{l}\text { Not } \\
\text { significant }\end{array}$ \\
\hline Science & 100 & 3307 & 33.07 & 6.766 & & & \\
\hline
\end{tabular}

It can be observed from the given table that the Environmental Awareness scores of Post-Graduate Arts and Science students are found to have mean score of 32.38 and 33.07 and S.D. is 6.143 and 6.766 respectively. The 't' ratio between two groups has been found out to be 1.87 which is less than 1.96 , so it is not significant at 0.05 level. It means that there exists no significant difference between Post-Graduate Arts and Science students regarding Environmental Awareness.

Thus the hypothesis that there exists no significant difference between Post-Graduate Arts and Science students regarding Environmental Awareness is accepted.

- $\quad$ COMPARISON OF MEAN, S.D. AND C.R. BETWEEN RURAL AND URBAN POSTGRADUATE STUDENTS

\begin{tabular}{|l|l|l|l|l|l|l|l|}
\hline GROUP & $\mathrm{N}$ & $\sum \mathrm{X}$ & $\mathrm{M}$ & & $\mathrm{SEd}$ & t-ratio & $\begin{array}{l}\text { Level } \\
\text { significance }\end{array}$ \\
\hline Urban & 100 & 3073 & 30.73 & 5.73 & & & significant \\
\hline Rural & 100 & 3307 & 33.07 & 6.766 & 0.875 & 6.053 & \\
\hline
\end{tabular}

It can be observed from the given table that the Environmental Awareness scores of Post-Graduate Rural and Urban students are found to have mean score of 30.73 and 33.07 and S.D. is 5.73 and 6.766 respectively. The ' $t$ ' ratio between two groups has been found out to be 6.053 which is less than 1.96 , so it is significant at 0.01 level. It means that there exists significant difference between Post-Graduate Rural and Urban students regarding Environmental Awareness.

Thus the hypothesis that there exists no significant difference between Post-Graduate Rural and Urban students regarding Environmental Awareness is rejected.

Educational Implications

Through formal education, Environmental Education can be imparted in the following three stages: 
At primary school level- At this stage, the emphasis should be made mostly on building up awareness, through by real life situations and conservations. At this level, Environmental Education would consist mainly of perceiving natural objects dimensions, plants and animals' etc. teaching strategy should include audio visual and field visits.

At secondary level- At this stage, general and easy concept of environment, various environmental problems, their solutions and various theoretical and practical contents, which increase the interest of students towards, Environmental Education, should be given preference in the syllabus.

At higher level- At this level, Environmental Education should be included in curriculum as a compulsory subject. Various national and international complicated problems of environment should also be included in the curriculum; research work should be given proper place in the curriculum. Besides, these, Environmental Education should be included in the curriculum of Teacher Training Institutions, Industrial Training Institutions, Polytechnics, Engineering Colleges, Extension Training Center, so that after receiving the training, when they engage in government and non-government services, the students will be able to expand the Environmental Education in society.

Environmental education is not restricted to in-class lesson plans. There are numerous ways children can learn about the environment in which they live. From experiential lessons in the school yard and field trips to national parks to after-school green clubs and school wide sustainability projects, the environment is a topic which is readily and easily accessible. Furthermore, celebration of Earth Day or participation in EE week (run through the National Environmental Education Foundation) is a great way to dedicate your lessons to environmental education. To be most effective, promote a holistic approach and lead by example, using sustainable practices in the classroom and school grounds and encouraging students and parents to bring environmental education into their home.

The final aspect of environmental education policies, but certainly not least important, is training individuals to thrive in a sustainable society. In addition to building a strong relationship with nature, American citizens must have the skills and knowledge to succeed in a 21 st century workforce. Thus, environmental education policies fund both teacher training and worker training initiatives. Teachers must be trained to effectively teach and incorporate environmental studies in their curricula. On the other hand, the current workforce must be trained or re-trained so that they can adapt to the new green economy. Environmental education policies that fund training programs are critical in educating citizens to prosper in a sustainable society.

\section{Conclusion}

The reality is very much accepted that in India more than $50 \%$ of the total population do not get the opportunity of formal education, therefore, only formal system of education is not sufficient for creating environment awareness among the general public, efforts should be made to each illiterate youth and adults, boys and girls. Emphasis should be given to environmental problem of local and regional relevance. Mass media such as radio, TV, newspapers, periodical, feature films and documentaries etc. can be used effectively in the expansion of Environmental Education among masses. In the remote and rural areas the formal and non-formal education is not widely spread, environmental knowledge, appreciation, interest and skill can be developed among people through sponsoring interesting environmental programs on TV and Radio. This purpose can also be fulfilled by telecast and broadcast of various advertisements such as disasters of deforestation and conservation of forests, trees, plantation, different types of pollution -its causes and solutions etc. Thus only Environmental Education can develop awareness towards environment in teachers, students as well as community at large, so that quality of our environment will be maintained between present and future. therefore to foster better knowledge, understanding and skills about environment, to bring awareness among people regarding the preservance of better environment and to present environmental degradation and continuous exploitation of natural resources. The need of Environmental Education cannot be overlooked.

\section{References}

[1]. Aggarwal,Y.P., The Science Of Educational Research, Nirmal Book Agency, Kurukshetra,1998

[2]. Aggarwal,Y.P., Statistical Methods: Concepts, Application And Computation, Sterling Publisher Pvt. Ltd..2000

[3]. Aggarwal, S.K. and Garg, R.K. , Environmental Issues And Research In India, Himanshu Publications, Udaipur,1988

[4]. Chandana, R.C., Environmental Awareness, Kalyani Publishers,New Delhi,1998

[5]. Sharma, P.D. Ecology And Environment, Rastogi Publications, Meerut 1998

\section{WEBSITES}

http://www.tropical-rainforest-animals.com/Environmental-Pollution.html

http://en.wikipedia.org/wiki/Environmental_education 